\title{
CYCLODEXTRIN GLYCOSYLTRANSFERASE FROM BACILLUS LICHENIFORMIS: OPTIMIZATION OF PRODUCTION AND ITS PROPERTIES
}

\author{
Paulo Roberto Martins Bonilha ${ }^{1}$; Vivian Menocci ${ }^{2}$; Antonio José Goulart ${ }^{1}$; \\ Maria de Lourdes Teixeira de Moraes Polizeli ${ }^{1}$; Rubens Monti ${ }^{1 *}$
}

'Departamento de Bioquímica e Química Tecnológica , Instituto de Química, Universidade Estadual Paulista "Júlio de Mesquita Filho", Araraquara, SP, Brasil; ${ }^{2}$ Departamento de Alimentos e Nutrição, Faculdade de Ciências Farmacêuticas, Universidade Estadual Paulista “Júlio de Mesquita Filho”, Araraquara, SP, Brasil

Submitted: May 24, 2005; Returned to authors for corrections: March 09, 2006; Approved: May 08, 2006

\begin{abstract}
Cyclodextrin glycosyltransferase (EC 2.4.1.19) is an enzyme that produces cyclodextrins from starch via an intramolecular transglycosylation reaction. An alkalophilic Bacillus strain, isolated from cassava peels, was identified as Bacillus licheniformis. CGTase production by this strain was better when potato starch was used as carbon source, followed by cassava starch and amylopectin. Glucose and amylose, on the other hand, acted as synthesis repressors. When the cultivation was supplemented with sodium ions and had the $\mathrm{pH}$ adjusted between 6.0 and 9.0, the microorganism maintained the growth and enzyme production capacity. This data is interesting because it contradicts the concept that alkalophilic microorganisms do not grow in this $\mathrm{pH}$ range. After ultrafiltration-centrifugation, one protein of $85.2 \mathrm{kDa}$ with CGTase activity was isolated. This protein was identified in plates with starch and phenolphthalein. Determination of the optimum temperature showed higher activities at $25^{\circ} \mathrm{C}$ and $55^{\circ} \mathrm{C}$, indicating the possible presence of more than one CGTase in the culture filtrate. $\mathrm{Km}$ and Vmax values were $1.77 \mathrm{mg} / \mathrm{mL}$ and $0.0263 \mathrm{U} / \mathrm{mg}$ protein, respectively, using potato starch as substrate.
\end{abstract}

Key words: cyclodextrin glycosyltransferase, CGTase production, Bacillus licheniformis, Bacillus $\beta$-CD

\section{INTRODUCTION}

Cyclodextrin glycosyltransferase (CGTase; EC 2.4.1.19) converts starch in non reducing, cyclic malto-oligosaccharides called cyclodextrins (CDs). The major types of CDs contain 6,7 and 8 glucose molecules linked by $\alpha(1-4)$ glycosidic bonds to form a ring and are named as $\alpha-\mathrm{CD}, \beta-\mathrm{CD}$ and $\gamma-\mathrm{CD}$, respectively. CDs have the ability to encapsulate other molecules within their ringed structures. The ability of these unusual molecules to form inclusion complexes, which can change the physical and chemical properties of guest molecules, offers a variety of potential uses for food, cosmetic and pharmaceutical industries $(3,22)$. According to Van Der Veen et al. (26) many factors involved in producing specificity of CGTases have been identified, including the identity, position and interactions of several amino acid residues that play an important role. Furthermore, crystalline complexes that are the results of this process are stable, a characteristic that can provide many benefits (22). A detailed history of the development of cyclodextrins up to 1956 was reviewed by French (6). The CGTases are known to be produced by various genera of the bacterial kingdom such as Bacillus, Klebsiella, Pseudomonas, Brevibacterium, Micrococus and Clostridium (9). Bacillus is the main genera, with various producing species $(1,2,3,8,17$, $19,20,21,27)$. They are also known to catalyze four different transferase reactions: cyclization, coupling, disproportionation, and hydrolysis (4). All known CGTases produce $\alpha$-, $\beta$ - and $\gamma$ CDs from starch in different reactions. CGTase that can

*Corresponding Author. Mailing address: Rodovia Araraquara-Jaú, Km 1, Campus. 14801-902, Araraquara, SP, Brasil. Tel. (+5516) 3301-6934. E-mail: montiru@fcfar.unesp.br 
synthesize predominantly one type of $\mathrm{CD}$ has commercial importance since the separation of a particular form of CD is expensive and time-consuming. The majority of the CGTases, especially from the alkaliphilic bacteria, convert starch into $\beta$ $\mathrm{CD}$ as the main product, but still in a mixture of CDs of different ratios (18). The industrial production of CGTase was made attractive only when alkaliphilic Bacillus species were introduced as producing organism (23). This paper reports the production optimization and some biochemical properties of a CGTase produced by a strain of Bacillus licheniformis isolated from cassava culture soil.

\section{MATERIALS AND METHODS}

\section{Strain and culture conditions}

The alkaliphilic Bacillus licheniformis was isolated from cassava peels harvested of organic soil in São Carlos, São Paulo, Brazil. The isolation was made from a suspension of cassava peels through dilution method in plates of Petri with solid media of Horikoshi and Akiba (14). The isolated microorganism was submitted to the microscopical analysis and presented morphology compatible with an aerobic positive Gram bacilli, presented positive catalase and motility, being characterized as pertaining to the Bacillus genera. The microorganism was later characterized as Bacillus licheniformis, according to the Bergey's manual.

\section{Growth of $B$. licheniformis in different cultivation conditions for CGTase production}

Pre-cultivation medium (14) was inoculated in the proportion of $10 \%(\mathrm{v} / \mathrm{v})$ in the culture medium for the production of CGTase and incubated at $37^{\circ} \mathrm{C}$, for $12 \mathrm{~h}$ and $130 \mathrm{rpm}$. Potato starch, cassava starch, amylopectin, amylose, potato starch + glucose, and glucose $(1 \% \mathrm{w} / \mathrm{v})$ were used as carbon sources. It was also tested the nutrient broth (NB) Difco with potato starch as carbon source. The capacity of growth of the microorganism in presence of 2.0, 5.0, 7.0, 10.0 and $15.0 \% \mathrm{NaCl}$ with $\mathrm{pH}$ adjusted to 10.0 was tested, and also in medium with potato starch supplemented with $0.6 \% \mathrm{NaCl}$ in $\mathrm{pH} 6.0,7.0,8.0$ and 9.0. After the growth, the cultures were centrifuged at $7425 \mathrm{~g}, 4^{\circ} \mathrm{C}, 20 \mathrm{~min}$. and the proteins were concentrated with 3 volumes of acetone at $4^{\circ} \mathrm{C}$.

\section{Qualitative analysis of CGTase}

The enzyme CGTase produced in different cultivation conditions ( $\mathrm{pH}$, carbon source and $\mathrm{NaCl}$ presence) was acetoneconcentrated and analyzed qualitatively with phenolphthalein applying $2 \mu \mathrm{L}$ aliquots of this concentrated in Petri plates with solid medium at $\mathrm{pH} 10.0$ and potato starch, cassava starch, amylopectin and amylose (Sigma) as substrate. The plates were incubated at $37^{\circ} \mathrm{C}$ for $24 \mathrm{~h}$. This methodology revealed the presence of CGTase activity in the culture filtrates through halo formation with good reproducibility.

\section{Determination of the specific activity of CGTase}

The cyclization activity was determined according to Makela (16). The enzyme was incubated in $1 \%(\mathrm{w} / \mathrm{v})$ starch potato in 50 $\mathrm{mM}$ Tris- $\mathrm{HCl}$ buffer, $\mathrm{pH} 8.0$, at $40^{\circ} \mathrm{C}$. Reaction samples were removed at $0,10,20$ and $30 \mathrm{~min}$. and the activities were interrupted at $100^{\circ} \mathrm{C}$, for $3 \mathrm{~min}$. The amount of cyclodextrin was determined by the decrease of the absorption at $550 \mathrm{~nm}$, after the addition of $1.2 \mathrm{~mL}$ phenolphthalein $3 \mathrm{mM}$ prepared in $500 \mathrm{mM}$ carbonate of sodium buffer, $\mathrm{pH} 10.0$ and $0.5 \mathrm{~mL}$ of reaction product. For the calibration curve $0.006-0.022 \mu \mathrm{mol} \beta-\mathrm{CD}$ solution in $50 \mathrm{mM}$ Tris-HCl buffer $\mathrm{pH} 8.0$ was used. An unit of CGTase activity was defined as the amount of enzyme that produces $1 \mu \mathrm{mol}$ of $\beta$-CD per minute, under the assay conditions. The specific activity was expressed in units of activity by milligram of protein. Protein concentration was estimated according to Hartree (12), using bovine serum albumin as pattern.

\section{Determination of the optimum temperature}

Two fractions of the culture filtrate were taken for the determination of the optimal hydrolysis temperature. The first fraction was concentrated with acetone $(1: 3 \mathrm{v} / \mathrm{v})$ and the supernatant from the centrifuged was discarded and the precipitate obtained was resuspended in water (precipitate 1). The second fraction was added of acetone $(1: 3 \mathrm{v} / \mathrm{v})$ and the decanted proteins (precipitate 2) were centrifuged $2230 \mathrm{~g}$, resuspended and dialyzed against distilled water $\left(12 \mathrm{~h}, 4^{\circ} \mathrm{C}\right)$. The supernatant removed from the precipitate 2 was centrifuged $2230 \mathrm{~g}$, and the precipitate was dialyzed for $12 \mathrm{~h}$, $4^{\circ} \mathrm{C}$ (precipitate 3 ). These precipitates were submitted to enzymatic assays $\left(25^{\circ} \mathrm{C}, 35^{\circ} \mathrm{C}, 40^{\circ} \mathrm{C}, 45^{\circ} \mathrm{C}, 55^{\circ} \mathrm{C}\right.$ and $\left.65^{\circ} \mathrm{C}\right)$.

\section{Ultra filtration-centrifugation and analysis by electrophoresis}

The proteins of the acetone-concentrated culture filtrates (precipitate 1) were submitted to treatments with Ultrafree 30 kDa NMWL and $100 \mathrm{kDa}$ NMWL Millipore membranes (2230g, $15 \mathrm{~min} .4^{\circ} \mathrm{C}$ ). Proteins retained by the membranes were recovered with Milli-Q water. These proteins and the filtrates were submitted to denaturing condition electrophoresis (15), using kit Amersham Biosciences LMW as markers (phosphorylase b $97.4 \mathrm{kDa}$; bovine serum albumin $66 \mathrm{kDa}$; ovalbumin $45 \mathrm{kDa}$; carbonic anhydrase $30 \mathrm{kDa}$; trypsin inhibitor $20.1 \mathrm{kDa}$; $\beta$-lactalbumin $14.4 \mathrm{kDa}$ ). The non-denaturing condition electrophoresis was carried out according to Davis (5) and it allowed the identification of CGTase activity in the gel, using two polyacrylamide identical gels, being one stained and the other put on a plate containing starch, agar and phenolphthalein ( $\mathrm{pH} 10.0)$ incubated at $50^{\circ} \mathrm{C}$ until the appearance of a halo of activity.

\section{Determination of the kinetic parameters}

The kinetic parameters of the enzyme obtained by ultra filtration-centrifugation were determined by its incubation with potato starch solution in concentration of 2, 4, 8, 12 and $16 \mathrm{mg} /$ 
$\mathrm{mL}(\mathrm{w} / \mathrm{v})$ in $50 \mathrm{mM}$ Tris- $\mathrm{HCl}$ buffer, $\mathrm{pH} 8.0$ at $55^{\circ} \mathrm{C}$, for $30 \mathrm{~min}$. The $\mathrm{Km}$ and Vmax values were estimated using the EadieHofstee plot.

\section{RESULTS AND DISCUSSION}

Growth of B. licheniformis in different culture conditions and qualitative analysis of the CGTase activity in distinct substrates

The growth of the B. licheniformis was studied in different conditions using Horikoshi and Akiba (14) medium, varying carbon sources, $\mathrm{pH}$ and sodium chloride concentrations. It was also tested the nutrient broth (NB) with potato starch (Table 1). After the growth of the microorganism in different conditions, the results demonstrated, through formation of the colorless halos, that it remained active and did not lose the capacity to produce the CGTase activity. It is known that Bacillus alkalophilics requires initial $\mathrm{pH} 9.0$ for the production of CGTase. However, this work verified that in culture medium added of $0.6 \% \mathrm{NaCl}$ the microorganism presented growth even at $\mathrm{pH} 6.0$, 7.0, 8.0 and 9.0. These data are similar to those reported from Tsai et al. (25) where the Bacillus Ya-B presented growth at $\mathrm{pH}$ 7.0 in culture medium added with $1.0 \% \mathrm{NaCl}$.

The results of the qualitative analysis of the CGTase (Table 1 and Fig. 1) in the plates with potato starch, cassava starch and amylopectin showed that the culture filtrate from experiments 1 , 2, 4, 8 and 13-16 had produced halo, confirming the presence of CGTase activity; however, in the plate where amylose was used

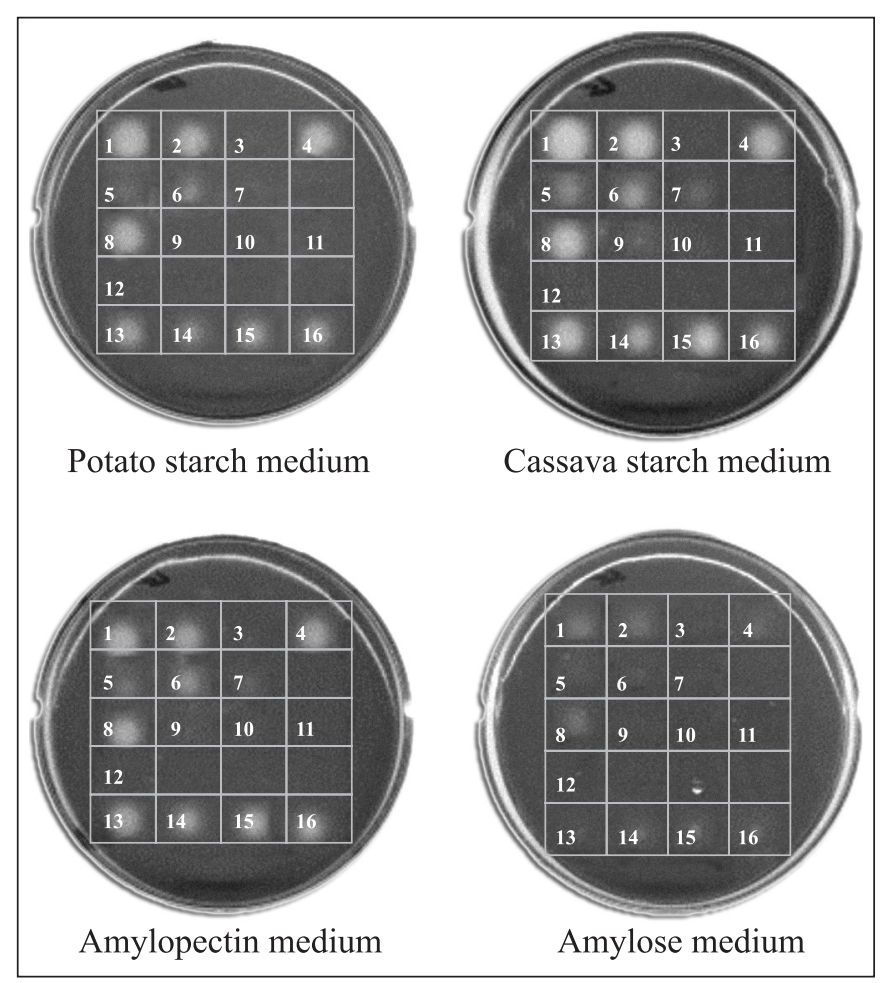

Figure 1. Qualitative analysis of CGTase activity on different substrates after enzyme production in distinct culture conditions described in Table 1.

Table 1. Growth analysis and CGTase production obtained in different media, carbon sources, $\mathrm{NaCl}$ concentrations and pH.

\begin{tabular}{|c|c|c|c|c|c|c|c|c|c|}
\hline \multirow[b]{2}{*}{ Exp. } & \multirow[b]{2}{*}{ Medium } & \multirow[b]{2}{*}{$\begin{array}{l}\text { Carbon } \\
\text { source }\end{array}$} & \multirow[b]{2}{*}{$\mathrm{NaCl}(\%)$} & \multirow[b]{2}{*}{$\mathrm{pH}$} & \multirow[b]{2}{*}{ Growth } & \multicolumn{4}{|c|}{ Substrate } \\
\hline & & & & & & $\begin{array}{l}\text { Potato } \\
\text { starch }\end{array}$ & $\begin{array}{c}\text { Cassava } \\
\text { starch }\end{array}$ & Amylopectin & Amylose \\
\hline 2 & HA & Cassava starch & 0 & 10.0 & + & + & + & + & - \\
\hline 3 & HA & Amylose & 0 & 10.0 & + & - & - & - & - \\
\hline 4 & HA & Amylopectin & 0 & 10.0 & + & + & + & + & - \\
\hline 6 & HA & Potato starch + glucose & 0 & 10.0 & + & \pm & \pm & \pm & - \\
\hline 7 & HA & Glucose & 0 & 10.0 & + & - & - & - & - \\
\hline 8 & HA & Potato starch & 2 & 10.0 & + & + & + & + & - \\
\hline 9 & HA & Potato starch & 5 & 10.0 & + & - & - & - & - \\
\hline 10 & HA & Potato starch & 7 & 10.0 & + & - & - & - & - \\
\hline 15 & HA & Potato starch & 0.6 & 8.0 & + & + & + & + & - \\
\hline 16 & HA & Potato starch & 0.6 & 9.0 & + & + & + & + & - \\
\hline
\end{tabular}

Note: HA - Horikoshi and Akiba (14) medium; NB - nutrient broth; (+): definite halo; (-): absence halo; ( \pm ): intermediate halo. 
as substrate, the halo formation was very discrete. Although amylose is a less complex substrate, it did not act as inductor of the CGTase production (experiment 3). The CGTase activity level was very small when the Horikoshi and Akiba (14) medium was substituted by the nutrient broth (experiment 5), being detected small halos in the plates with cassava starch and amylopectin. It is possible that glucose acts as repressor of the synthesis of CGTase, since the culture filtrate of experiment 7 did not lead to the halo formation in none of the plates. This fact is strengthened by small formed halos when the growth occurred in starch + glucose (experiment 6). Culture filtered from media with 5 to $15 \% \mathrm{NaCl}$ concentrations (experiments 9 to 12 ) had not presented halos in any of the plates.

\section{CGTase specific activity}

Specific activities were determined using culture filtrates from experiments 1 to 8 and 13 to 16 , using potato starch as substrate (Table 2). The highest specific activity was observed in the culture filtrate where potato starch was used as carbon source (experiment 1 ); it is also possible to observe that the cassava starch and amylopectin culture filtrates presented $65 \%$ of the maximum activity. This result agrees to the qualitative analysis previously described. The enzymatic activity in potato starch + glucose culture (experiment 6 ) was about $25 \%$ and in the glucose culture (experiment 7) there was not CGTase production. These data indicate that glucose exerts repressor effect of the synthesis enzymatic. Similar results were reported by Gawande (11) with $B$. firmus which not produced CGTase in the presence of simple sugars. The results showed also that the specific activities in culture filtrates with $\mathrm{NaCl}$ or $\mathrm{Na}^{+}$media (experiments 8, 13, 14, 15 and 16) were minor than those observed in the experiment 1 . All the experiments were followed by reducing sugar determination using DNS, to make sure that we were not working with amylases.

\section{Identification of the CGTase in polyacrylamide gel}

Proteins of the filtrate culture from potato starch medium were concentrated with acetone and submitted to $8 \%$ PAGE. After the electrophoretic migration, half of a gel was revealed for proteins according to Heukeshoven and Dernik (13) and another half was placed on a plate with $1 \%$ starch, $3 \mathrm{mM}$ phenolphthalein and 2\% agar. After the migration in the polyacrylamide gel, the CGTase activity was identified through the halo formation next to front (Fig. 2).

\section{Determination of the optimum hydrolysis temperature}

For the determination of the optimum hydrolysis temperature of CGTase produced in potato starch medium, precipitates 1,2

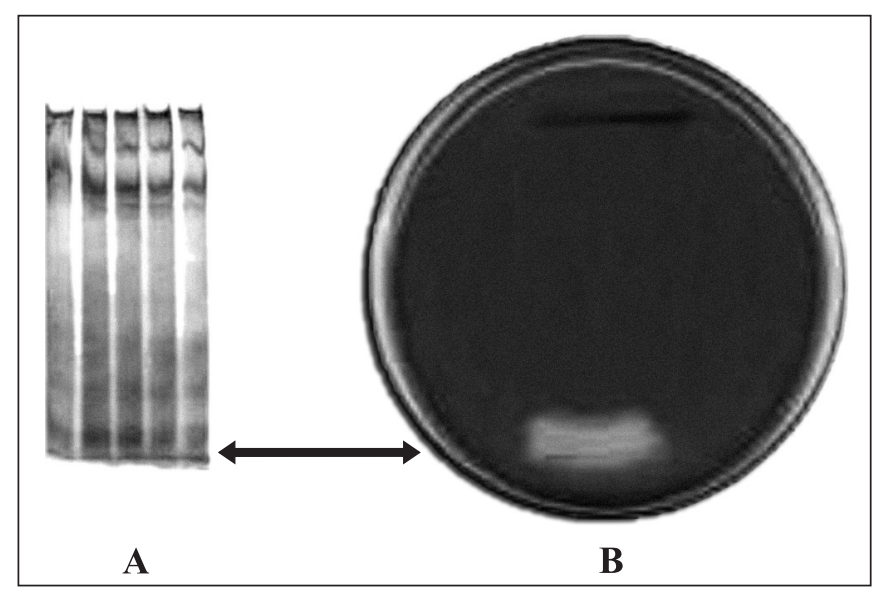

Figure 2. (A) 8\% PAGE of proteins produced by B. licheniformis. (B) Identification of the CGTase activity (encapsulation halo) using potato starch as substrate and phenolphthalein.

Table 2. Specific enzyme activities of CGTase from different cultures.

\begin{tabular}{lcccc}
\hline \multicolumn{1}{c}{ Carbon source* } & $\mathrm{pH}$ & Protein $\mathrm{mg} / \mathrm{mL}$ & ActivityU/mL & Specific activity $\mu \mathrm{mol} / \mathrm{mg}$ protein \\
\hline Potato starch (1) & 10.0 & $12.59 \pm 0.63$ & $0.162 \pm 0.008$ & $0.0129 \pm 0.0006$ \\
Cassava starch (2) & 10.0 & $12.61 \pm 0.63$ & $0.105 \pm 0.005$ & $0.0083 \pm 0.0004$ \\
Amylose(3) & 10.0 & $9.71 \pm 0.49$ & 0 & 0 \\
Amylopectin (4) & 10.0 & $10.84 \pm 0.54$ & $0.087 \pm 0.004$ & $0.0080 \pm 0.0004$ \\
Potato starch (5)** & 10.0 & $10.13 \pm 0.51$ & $0.042 \pm 0.002$ & $0.0042 \pm 0.0002$ \\
Potato starch and glucose (6) & 10.0 & $11.21 \pm 0.56$ & $0.036 \pm 0.002$ & $0.0032 \pm 0.0002$ \\
Glucose (7) & 10.0 & $11.51 \pm 0.58$ & 0 & 0 \\
Starch $+2.0 \% \mathrm{NaCl}(8)$ & 10.0 & $9.96 \pm 0.50$ & $0.069 \pm 0.003$ & $0.0069 \pm 0.0004$ \\
Starch $+0.1 \mathrm{M} \mathrm{Na}^{+}(13)$ & 6.0 & $11.43 \pm 0.57$ & $0.033 \pm 0.002$ & $0.0029 \pm 0.0001$ \\
Starch $+0.1 \mathrm{M} \mathrm{Na}^{+}(14)$ & 7.0 & $11.42 \pm 0.55$ & $0.032 \pm 0.002$ & $0.0028 \pm 0.0001$ \\
Starch $+0.1 \mathrm{M} \mathrm{Na}^{+}(15)$ & 8.0 & $11.52 \pm 0.58$ & $0.037 \pm 0.002$ & $0.0032 \pm 0.0002$ \\
Starch $+0.1 \mathrm{M} \mathrm{Na}^{+}(16)$ & 9.0 & $11.51 \pm 0.57$ & $0.082 \pm 0.004$ & $0.0072 \pm 0.0004$ \\
\hline
\end{tabular}

* Numbers represent the experiments of Table 1; ** Nutrient broth (Difco). Results represent media from three determinations. 
and 3 (described in Method) were used. The precipitate 1 was constituted of high and low molecular mass proteins plus carbohydrates; the precipitate 2 was constituted of high molecular mass proteins with low amount of carbohydrates; and the precipitate 3 was constituted of low molecular mass proteins with high molecular mass carbohydrates. CGTases from Bacillus showed optimum temperature between $45^{\circ} \mathrm{C}$ and $80^{\circ} \mathrm{C}$. Martins and Hatti-Kaul (18) observed optimum temperature of $55^{\circ} \mathrm{C}$ for a Bacillus agaradhaerens strain. The results obtained with precipitates 1,2 and 3 showed maxima activities in two different temperatures $\left(25^{\circ} \mathrm{C}\right.$ and $\left.55^{\circ} \mathrm{C}\right)$, allowed to raise the hypothesis that the presence of carbohydrates that follow proteins during the process of concentration and/or centrifugation of the culture filtrate (precipitate 1) can have protective effect in protein structure. Another hypothesis is the presence of more than one enzyme with CGTase activity, as demonstrated in Fig. 2.

\section{Ultrafiltration-centrifugation}

The CGTase produced by B. licheniformis that presented activity next to the gel front in $8 \%$ PAGE (Fig. 2) was purified to homogeneity through ultrafiltration-centrifugation procedure, using Ultrafree MC Millipore membranes. Two membranes were used, $100 \mathrm{kDa}$ and $30 \mathrm{kDa}$, and four protein fractions were obtained: two fractions were retained by the membranes (MW superior to $100 \mathrm{kDa}$ and $30 \mathrm{kDa}$ ) and two were filtered (MW inferior to $100 \mathrm{kDa}$ and $30 \mathrm{kDa}$ ). Fig. 3A shows the $8 \%$ PAGE proteins profile present in these samples and Fig. 3B shows the CGTase qualitative identification in the medium containing potato starch and phenolphthalein. The results also showed that the sample of MW superior to $30 \mathrm{kDa}$ presented CGTase positive activity (halo formation), while the sample of MW inferior of $30 \mathrm{kDa}$ did not present any activity. Both samples of MW inferior and superior to $100 \mathrm{kDa}$ presented halo formation. These results suggest that CGTase presents MW near to 100 $\mathrm{kDa}$, since a small amount of enzyme was filtered and another part was retained in the $100 \mathrm{kDa}$ membrane after the centrifugation. As it can be verified, CGTase activities correspond to the proteins with larger migration in PAGE. Furthermore, the results showed that the sample of MW inferior to $100 \mathrm{kDa}$ presented only one protein band with enzymatic activity, showing the purification by this process.

\section{Estimate of the apparent molecular weight}

The apparent molecular weight of the CGTase purified was 85.2 kDa by $12 \%$ SDS-PAGE (Fig. 4). Martins and Hatti-Kaul (18) determined for CGTase of Bacillus sp. molecular mass between 33 and $103 \mathrm{kDa}$. CGTase of the Bacillus sp. AL-6 the molecular mass was $74 \mathrm{kDa}$ (7) and $67 \mathrm{kDa}$ for Bacillus sp. no 199 (28). Thermococcus sp CGTase presented an apparent molecular mass of $83 \mathrm{kDa}(24)$ and one produced by Bacillus alkalophilic of Brazilian soil had molecular mass of $77.58 \mathrm{kDa}(19)$.

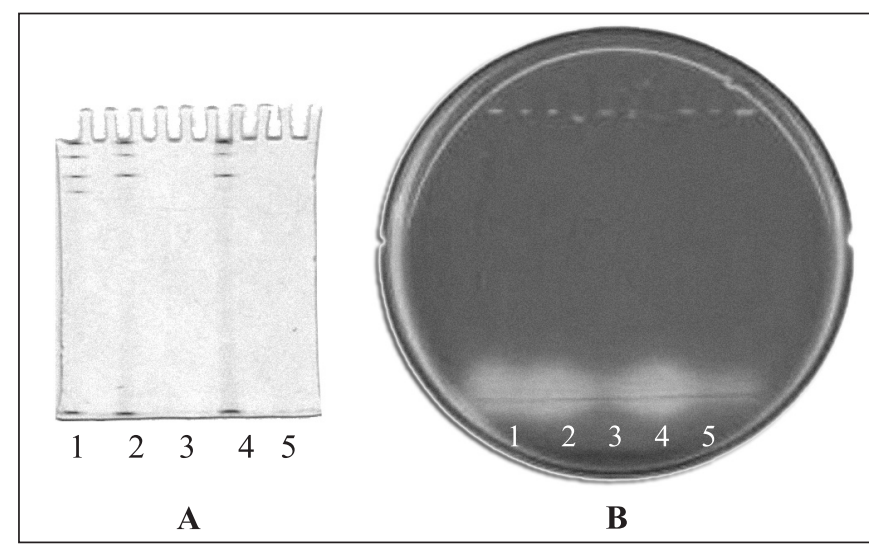

Figure 3. (A) $8 \%$ PAGE pH 8.9 of the fractions obtained through ultrafiltration-centrifugation. Lane 1: Sample without ultrafiltration-centrifugation; Lane 2: Fraction of superior MW $30 \mathrm{kDa}$; Lane 3: Fraction of inferior MW $30 \mathrm{kDa}$; Lane 4: Fraction of superior MW $100 \mathrm{kDa}$; Lane 5: Fraction of inferior MW 100 $\mathrm{kDa}$. (B) Qualitative identification of CGTase activity in the plate with potato starch and phenolphthalein from polyacrylamide gel.

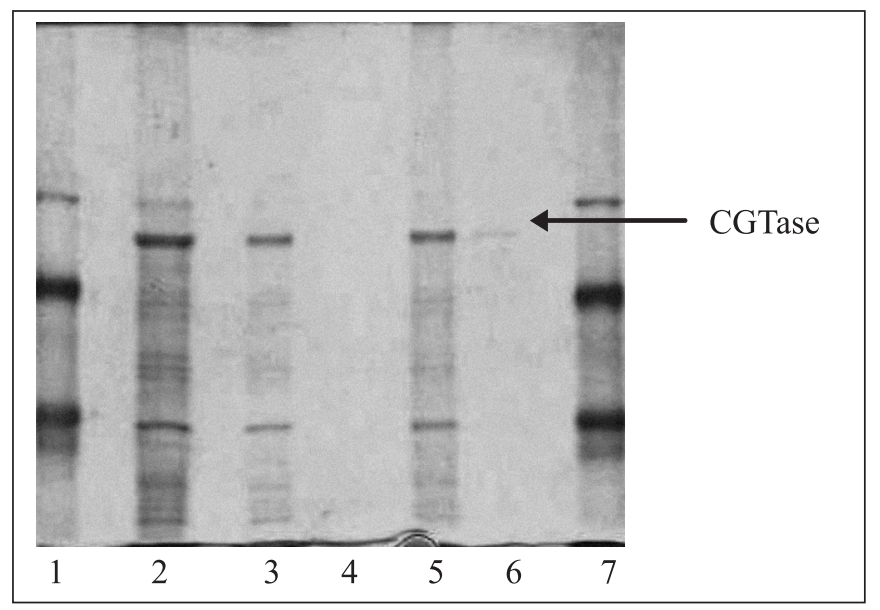

Figure 4. 12\% SDS-PAGE of the samples obtained through of ultrafiltration-centrifugation. Lanes 1 and 7: Molecular weight marker; Lane 2: Acetone-concentrated culture filtrate; Lane 3: Protein of superior MW $30 \mathrm{kDa}$; Lane 4: Protein of inferior MW $30 \mathrm{kDa}$; Lane 5: Protein of superior MW $100 \mathrm{kDa}$; Lane 6: Protein of inferior MW $100 \mathrm{kDa}$.

\section{Kinetic parameters}

$\mathrm{Km}$ and Vmax were estimated to be $1.77 \mathrm{mg} / \mathrm{mL}$ and 0.0263 U/mg prot., respectively (Fig. 5). These results showed that the enzyme presented high affinity for the substrate, when compared with literature data. Gawande et al. (9) determined $\mathrm{Km}$ value of $1.21 \mathrm{mg} / \mathrm{mL}$ for CGTase from Bacillus firmus using 
starch. Gawande and Patkar (10) reported $\mathrm{Km}$ of $1.35 \mathrm{mg} / \mathrm{mL}$ for CGTase of Klebsiella pneumoniae AS-22 using soluble starch. These values are slightly inferior to those obtained in the present work. Martins and Hatti-Kaul (18) determined Km of $21.2 \mathrm{mg} /$ $\mathrm{mL}$ using starch for the Bacillus agaradhaerens CGTase.

The purification and characterization showed that the studied enzyme is really a CGTase because there was no amylolytic activity in the obtained culture filtrate. Km value of $1.77 \mathrm{mg} / \mathrm{mL}$ indicates that the enzyme has high affinity with the substrate potato starch. Optimal determined temperature of $55^{\circ} \mathrm{C}$ is interesting for the industrial production of ciclodextrins by this CGTase. The method used for qualitative analysis is interesting, fast and reproductive.

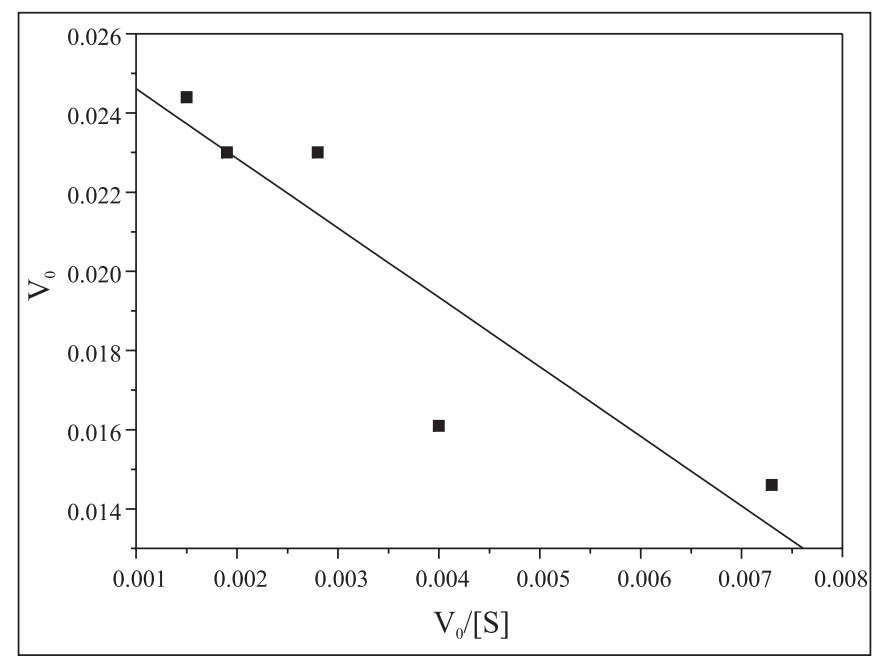

Figure 5. Eadie-Hofstee plot for the determination of $\mathrm{Km}$ and Vmax. CGTase was assayed in $50 \mathrm{mM}$ Tris- $\mathrm{HCl}$ buffer, $\mathrm{pH} 8.0$ at $55^{\circ} \mathrm{C}$, for $30 \mathrm{~min}$. using potato starch as substrate.

\section{ACKNOWLEDGEMENTS}

Vivian Menocci thanks Fundação de Amparo à Pesquisa do Estado de São Paulo -FAPESP (Proc. 02/09889-6) and Antonio José Goulart thanks Conselho Nacional de Desenvolvimento Científico e Tecnológico - CNPq (Proc. 141627/03-4) for the financial support.

\section{RESUMO}

\section{Cyclodextrina glycosyltransferase de Bacillus licheniformis: otimização da produção e suas propriedades}

Ciclodextrina glicosiltransferase (EC 2.4.1.19) é uma enzima que produz ciclodextrinas a partir de amido via transglicosilação intramolecular. Uma cepa de Bacillus alcalofílico, isolada de cascas de mandioca, foi identificada como Bacillus licheniformis. A produção de CGTase por esta cepa foi melhor quando amido de batata foi utilizado como fonte de carbono, seguido por amido de mandioca e amilopectina. Glicose e amilose, por outro lado, atuaram como repressor de síntese desta enzima. Quando o cultivo foi suplementado com íons sódio e teve o pH ajustado entre 6,0 e 9,0, o microrganismo manteve a capacidade de crescimento e de produção da enzima. Este dado é interessante pois contraria o conceito de que microrganismos alcalofílicos não apresentam crescimento nesta faixa de $\mathrm{pH}$. Após ultrafiltração-centrifugação, uma proteína de $85,2 \mathrm{kDa}$ com atividade de CGTase foi isolada. Esta proteína foi identificada em placas contendo amido e fenolftaleína. A determinação da temperatura ótima mostrou atividades mais elevadas em $25^{\circ} \mathrm{C}$ e $55^{\circ} \mathrm{C}$, indicando a possível presença de mais de uma CGTase no filtrado de cultura. Valores de $\mathrm{Km}$ e Vmax foram $1,77 \mathrm{mg} / \mathrm{mL}$ e 0,0263 U/mg proteína, respectivamente, usando amido de batata como substrato.

Palavras-chave: ciclodextrina glicosiltransferase, produção de CGTase, Bacillus licheniformis, $\beta-\mathrm{CD}$ de Bacillus

\section{REFERENCES}

1. Abdel-Naby, M.A.; Reyad, R.M.; Abdel-Fattah, A.F. Biosynthesis of cyclodextrin glucosyltransferase by immobilized Bacillus amyloliquefaciens in batch and continuos cultures. Biochem. Eng. J., 5, 1-9, 2000.

2. Akimaru, K. Purification and properties of Bacillus coagulans cyclomaltodextrin glucanotransferase. J. Ferm. Bioeng., 71, 322328, 1991.

3. Bender, H. Production, characterization, and application of cyclodextrins. Adv. Biotechnolog. Proc., 6: 31-71, 1986.

4. Bovetto, L.J.; Backer, D.P.; Villette, J.R.; Sicard, P.J.; Bouquelet, J.L. Cyclomaltodextrin glucanotransferase from Bacillus circulans E192. Biotechnol. Appl. Biochem., 15, 48-68, 1992.

5. Davis, B.J. Disc electrophoresis II. Method and application to human serum proteins. Ann. N. Y. Acad. Sci., 121, 404-427, 1964.

6. French, D. The Schardinger dextrins, In: Wolfram, M.L.; Tipson, R.S. (eds). Advances in Carbohydrate Chemistry. Academic Press, New York, 1957, p.189-260, v.12.

7. Fujita, Y.; Tsubouchi, H.; Inagi, Y.; Tomita, K.; Ozaki, A.; Nakanishi, K. Purification and properties of cyclodextrin glycosyltransferase from Bacillus sp. AL-6. J. Ferment. Bioeng., 70, 150-154, 1990.

8. Galvin, N.M.; Kelly, C.T.; Fogarty, W.M. Purification and properties of the cyclodextrinase of Bacillus sphaericus ATCC 7055. Appl. Microbiol. Biotechnol., 42, 46-50, 1994.

9. Gawande, B.N.; Goel, A.; Patkar, A.Y.; Nene, S.N. Purification and properties of a novel raw starch degrading cyclodextrin glucanotransferase from Bacillus firmus. Appl. Microbiol. Biotechnol., 51, 504-509, 1999.

10. Gawande, B.N.; Patkar, A.Y. Purification and properties of a novel raw starch degrading cyclodextrin glucanotransferase from Klebsiella pneumoniae AS-22. Enzyme Microb. Technol., 28, 735-743, 2001.

11. Gawande, B.N.; Singh, R.K.; Chauhan, A.K.; Goel, A.; Patkar, A.Y. Optimization of cyclomaltodextrin glucanotransferase production from Bacillus firmus. Enzyme Microbiol. Technol., 22, 288-291, 1998. 
12. Hartree, E.F. Determination of protein: A modification of the Lowry method that gives a linear photometric response. Anal. Biochem., 48, 422-427, 1972.

13. Heukeshoven, J.; Dernik, R. Simplified method for silver staining of proteins in polyacrylamide gels and the mechanism of silver staining. Electrophoresis, 6, 103-112, 1985.

14. Horikoshi, K.; Akiba, T. Alkalophilic microorganisms, a new microbial world, Springer, Berlin, 1982.

15. Laemmli, U.K. Cleavage of structural proteins during the assembly of the head of bacteriophage T4. Nature, 227, 680-685, 1970.

16. Makela, M.J.; Paavilainen, S.K.; Kopela, T.K. Colorimetric determination of $\beta$-cyclodextrin: two assay modification based on molecular complexation of phenolphthalein. J. Biochem. Biophys. Method., 14, 85-92, 1987.

17. Makela, M.J.; Paavilainen, S.K.; Korpela, T.K. Growth dynamics of cyclomaltodextrin glucanotransferase producing Bacillus circulans var. alkalophilus. Can. J. Microbiol., 36, 176-182, 1990.

18. Martins, R.F.; Hatti-Kaul, R.A. New cyclodextrin glycosyltransferase from an alkaliphilic Bacillus agaradhaerens isolate: purification and characterization. Enzyme Microb. Technol., 30, 116-124, 2002.

19. Matioli, G.; Zanin, G.M.; Guimarães, M.F.; Moraes, F.F. Production and purification of CGTase of alkalophilic Bacillus isolated from Brazilian soil. Appl. Biochem. Biotechnol., 70-72, 267-275, 1998.

20. Pocsi, J.; Nogrady, N.; Liptak, A.; Szentirmai, A. Cyclodextrins are likely to induced cyclodextrin glycosyltransferase production in Bacillus macerans. Folia Microbiol., 43, 71-74, 1998.
21. Ramakrishna, S.V.; Sa Swathi, N.; Sheela, R.; Jamuna, R. Evaluation of solid, slurry, and submerged fermentations for the production of cyclodextrin glycosyltransferase by Bacillus cereus. Enzyme Microb. Technol., 16, 441-444, 1994.

22. Shahidi, F.; Xiao-Qing, H. Encapsulation of food ingredients. Crit. Rev. Food Sci. Nut., 33, 501-547, 1993.

23. Starnes, R.L. Industrial potential of cyclodextrin glycosyl transferases. Cereal Food World, 35, 1094-1099, 1990.

24. Tachibana, Y.; Kuramura, A.; Shirasaka, N.; Suzuki, Y.; Yamamoto, T.; Fujiwara, S.; Takagi, M.; Imanaka, T. Purification and characterization of an extremely thermostable cyclomaltodextrin glucanotransferase from a newly isolated hyperthermophilic archeon, a Thermococcus sp. Appl. Environ. Microbiol., 65, 1991-1997, 1999.

25. Tsai, Y.; Juang, R.; Lin, S.; Chen, S.; Yamasaki, M.; Tamura, G. Production and further characterization of an alkaline elastase produced by alkalophilic Bacillus strain Ya-B. Appl. Environ. Microbiol., 54, 3156-3161, 1988.

26. Van Der Veen, B.A.; Uitdehaag, J.C.M.; Dijkstra, B.W.; Dijkhuizen, L. Engineering of cyclodextrin glicosyltransferase reaction and product specificity. Biochim. Biophys. Acta, 1543, 336-360, 2000.

27. Yin, D.G.; Sato, H.H.; Park, Y.H.; Park, Y.K. Production of cyclodextrin from starch by cyclodextrin glycosyltransferase from Bacillus firmus and characterization of purified enzyme. J. Ind. Microbiol. Biotechnol., 18, 402-405, 1997.

28. Yoshida, A.; Iwasaki, Y.; Akiba, T.; Horikoshi, K. Purification and properties of cyclomaltodextrinase from alkalophilic Bacillus sp. $J$. Ferment. Bioengineer, 71, 226-229, 1991. 